\title{
MANAJEMEN ZAKAT SEBAGAI PENYEIMBANG PEREKONOMIAN UMAT
}

\author{
Raja Hesti Hafriza ${ }^{1}$, Firdaus ${ }^{2}$, Ahmad Chuzairi ${ }^{3}$ \\ STAIN Sultan Abdurrahman Kepulauan Riau \\ ${ }^{1}$ rajahesti27@gmail.com \\ 2 apek.firdaus@gmail.com \\ 33amad1991.ac@gmail.com
}

\begin{abstract}
Abstrak
Zakat adalah salah satu solusi alternatif untuk mengurangi kemiskinan. selain menjadi pilar Islam, zakat mampu menyelesaikan masalah sosial masyarakat muslim. Kondisi sosial masyarakat saat ini berada di garis kemiskinan sehingga begitu banyak orang hidup dalam kekurangan. Oleh karena itu, zakat mampu menyelesaikan masalah jika diimplementasikan dengan manajemen yang baik. Dari beberapa litelatur penelitian terdahulu, penulis mencoba untuk merekonstruksi beberapa ide yang tersebar itu. Hasil penelitian ini memperlihatkan bahwa pola manajemen Islami sangat berbeda dengan manajemen konvensional. Sehingga manajemen Islami harus menjadi standar dalam praktik pengelolaan zakat yang dilakukan oleh organisasi pengelola zakat, yakni dengan perinsip iman, kepemimpinan, manajemen dan administrasi yang baik. Dengan standar manajemen Islami, zakat akan mampu dikumpulkan, dikelola, dimanfaatkan dan didistribusikan sesuai dengan ketetuan syariat Islam.
\end{abstract}

\begin{abstract}
Abstrak: Zakah is one of the alternative solutions to reduce poverty. Besides being a pillar of Islam, zakah is able to resolve the social problems of Muslim society. The social condition of society today is still in the poverty line. So many people live with shortages. Therefore, zakah can solve the problem if it is implemented in a good management. From several related studies, the researcher tried to reconstruct some ideas that were spread. The results of this study indicates that Islamic management patterns are very different with conventional management. So that Islamic management must be a standard in the practice of zakah management carried out by zakah management organization. They should be conducted with the principles of faith, leadership, management and good administration. With Islamic management standards, zakat will be able to be collected, managed, utilized and distributed based on the conditions of Islamic law.
\end{abstract}

Keywords: amil, zakat, kesejabteraan sosial, ekonomi kerakyatan

\section{Pendahuluan}

Manusia sebagai makhluk sosial yang diciptaan Allah subhanabu wata'ala yang tidak dapat hidup secara individu tanpa orang lain. Islam sebagai Agama samawi selama 14 Abad lalu yang dibawa oleh Rasulullah SAW juga telah memberikan konsep tentang kehidupan antar sesama manusia. Kehidupan sosial menjadi suatu yang diprioritaskan oleh Rasulullah sebagai jalan dakwahnya, ini merupakan tujuan utama dari ajaran Islam sebagai agama yang komprehensif dan juga mengutamakan kepentingan sosial dalam bermuamalah. Bentuk kepedulian sosial yang pernah Rasulullah SAW ajarkan kepada umatnya adalah memberikan hak orang lain dari rezeki yang kita peroleh yang disebut dengan istilah Zakat. Secara teknis, zakat merupakan tindakan Ibadah Muamalah yang

Perada, Vol. 1, No. 1, Juni 2018 diwajibkan atas setiap Muslim yang memiliki kekayaan sama dengan atau melebihi jumlah nisabnya harus membayar zakat dengan jumlah yang telah ditentukan kepada orang yang berhak menerimanya. ${ }^{1}$

Dalam istilah ekonomi, zakat merupakan suatu tindakan pemindahan harta dari golongan yang kaya kepada golongan miskin. Oleh karena itu pelarangan riba dan perintah membayar zakat (Q.S al-Baqarah/2:276) adalah dua konsep yang selalu dikemukakan setiap pembahasan yang berhubungan dengan sosial ekonomi Islam. ${ }^{2}$ Perlu digarisbawahi

${ }^{1}$ Mek Wok Mahmud and Sayed Sikandar Shah, The Use of Zakat Revenue in Islamic Financing: Jurisprudential Debate and Practical Feasibility, Studies in Islam and the Middle East, Vol. 6 No.1 (2009), hal.1

2 Amalia dan Kasyful Mahalli, Potensi Dan Peranan Zakat Dalam Mengentaskan Kemiskinan Di kota medan, 
bahwa zakat bukan hanya sekadar bagian dari rukun Islam yang menjadi suatu kewajiban seorang muslim, namun jika dipahami dari segi konsep filosofis bahwa zakat mampu mensejahterakan masyarakat secara umum, karena dengan berzakat akan menciptakan suasana yang harmonis dan mempunyai rasa sikap saling peduli terhadap sesama yang lebih membutuhkan. ${ }^{3}$

Dengan demikian, konsep zakat telah memberikan contoh bahwa agama islam sangat memperhatikan umatnya yang membutuhkan. Dalam hal ini zakat berfungsi sebagai redistribusi kekayaan yang adil dalam pendapatan, yang diberlakukan melalui kewajiban moral dan kebijakan fiskal ${ }^{4}$ dalam kondisi ekonomi dan sosial. Beberapa ulama kontemporer menilai bahwa perlu adanya pelembagaan zakat agar potensi, pemanfaatan dan pendayagunaannya mampu mencapai tujuan disyariatkannya. Beberapa negara juga telah menerapkan pengelolaan zakat melaluil lembaga-lembaga resmi, baik yang didirikan pemerintah maupun swasta. ${ }^{5}$

Di Indonesia, zakat telah menjadi amanat undang-undang. Pengelolaan zakat, tidak lagi melalui Badan Amil Zakat (BAZ) dan Lembaga Amil Zakat (LAZ) sebagai lembaga nonstruktural dalam pemerintah, melainkan juga berkesempatan dilakukan oleh organisasi pengelola zakat (OPZ) lainnya. ${ }^{6} \mathrm{Di}$ tengah banyaknya OPZ, diperlukan suatu manajemen yang baik agar seluruh kegiatannya berjalan efektif. Sebab, pada dasarnya, dana zakat merupakan dana umat yang perlu

Jurnal Ekonomi dan Keuangan, Vol. 1, No.1 (2012), hal. 72

3 Pembahasan lainnya tentang dimensi sosial ini, lihat Hafidhuddin, Didin. Zakat dalam perekonomian modern. Gema Insani (2002), hal. 66.

${ }^{4}$ Saidurrahman, "The Politics Of Zakat Management In Indonesia The Tension Between BAZ and LAZ", Journal of Indonesian Islam, Vol. 7 No. 2 (2013), hal. 367

5 Lihat kajian Aan Jailani, Manajemen Zakat di Indonesia dan Brunei Darussalam, Cirebon: Nurjadi Press, 2015.

${ }^{6}$ Beberapa nama lembaga zakat, wakat seperti Dompet Dhuafa, Rumah Zakat, LAZIZ Nahdlatul Ulama, Yatim Mandiri, dan lainnya. Selain zakat, organisasi ini juga mengelola dana infak, sedekah dan wakaf. Dalam laman situ Badan Amil Zakat Nasional (Baznas) tedapat 22 lembaga zakat berskala nasional dan daerah. Lihat http://zakat.or.id/daftar-lembaga-amilzakat. Diakses 5 Agustus 2018. digunakan kemaslahatan bersama. Peruntukan dana tersebut juga sudah sangat jelas dalam hukum Islam, yakni terhadap delapan golongan. Tentu diharapkan agar dana lebih banyak terserap untuk kepentingan masyarakat dari pada digunakan untuk internal OPZ. Di sinilah letak penting kajian manajemen zakat yang ideal dapat diimplementasikan dalam realitasnya. Artikel ini hendak mengkaji manajemen zakat sebagai instrumen untuk pemberdayaan umat melalui telaah kepustakaan dari para peneliti sebelumnya.

\section{Manajemen Islami}

Manajemen berasal dari bahasa Inggris "management", jamak dari "managements", yang diartikan dalam bahasa Indonesia 1) proses penggunaan sumber daya secara efektif untuk pencapaian sasaran. 2) pejabat pimpinan yang bertanggung jawab atas jalannya perusahaan atau organisasi. Kesimpulan yang dapat diambilnya adalah manajemen mempunyai peranan yang amat menentukan bagi kesuksesan suatu program bahkan boleh disebut tanpa manajemen yang baik, mustahil suatu organisasi atau bisnis akan mencapai suatu kesuksesan. ${ }^{7}$

Manakala pengertian manajemen yang umum itu diberi prediket "Islam" maka konotasinya menjadi terbatas sesuai dengan aturan yang berlaku dalam ajaran Islam. Dengan demikian "manajemen Islami" adalah proses penggunaan sumber daya secara efektif dan bertanggung jawab untuk mencapai sasaran yang telah ditetapkan organisasi sesuai ajaran Islam yang baku. Ada beberapa poin penting dalam sistem manajemen Islami yang menjadi dasar agar sebuah lembaga yang digerakkan mampu berkembang sesuai dengan konsep Islam. ${ }^{8}$

Pertama, iman. Inti penggerak manajemen Islami itu ialah Iman. Boleh disebut "Iman" itu sebagai generator penggerak organisasi, sehingga gerak atau kiprah perusahaan itu akan selalu terkendali sesuai koridor "Iman" itu. Adanya konsep iman inilah yang menjadi garis pemisah antara

\footnotetext{
${ }^{7}$ Nashrudin Baidan dan Erwati Aziz, Etika Islam dalam Berbisnis, (Yogyakarta: Pustaka Pelajar, 2014), hal.100.

${ }^{8}$ Ibid
} 
manajemen Islami dengan manajemen sekuler (non Islami). Dalam manajemen sekuler itu yang menjadi inti penggerak dalam suatu organisasi adalah rasio.Untuk lebih jelasnya bisa dilihat dalam bagan di bawah. ${ }^{9}$

\section{Bagan Sistem Manajemen}

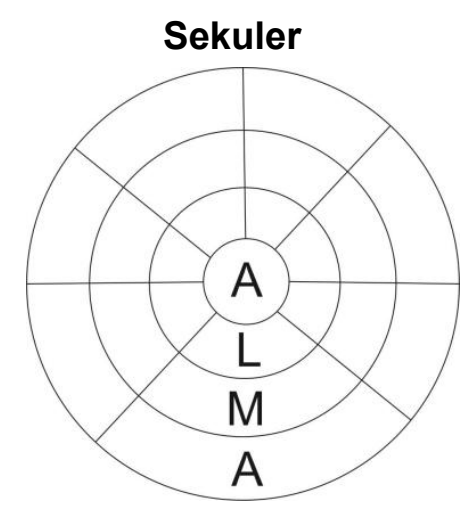

Keterangan:

A: Akal (rasio)

L: Leadership

M: Manajemen

A: Administrasi

Di sini tampak jelas bahwa dalam manajemen Islami itu "iman" yang ditonjolkan bukan "akal", karena akal tidak selamanya dapat diandalkan untuk membimbing kehidupan dimuka bumi, termasuk mengatur suatu organisasi.

Kedua, leadership. Manajemen yang Islami sebagaimana dijelaskan, itu tidak akan terwujud tanpa leadership (kepemimpinan) yang baik, amanah, jujur dan professional. Iman yang menjadi dasar tidak bermakna apa-apa, apabila tidak didukung oleh leadership yang mantap.

Ketiga, sistem managemen. Disamping dilandasi Iman dan Leadership sebagai bagian dari berjalannya suatu organisasi secara maksimal, perlu juga dilandasi dengan sistem manajemen yang baik. Jika seorang manajer ingin sukses, maka beberapa prinsip dalam managemen yang diajarkan dalam islam perlu dijadikan patokan, yakni meliputi motivasi, janji dan ancaman, penetapan keputusan, komunikasi, rekrutmen staff, pengawasan, perencanaan, kepemimpinan, pengorganisasian.

${ }^{9}$ Ibid, hal.102

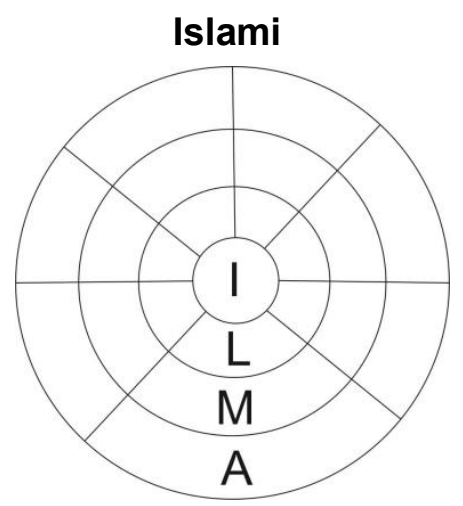

Keterangan:

I: Islami

L: Leadership

M: Manajemen

A: Administrasi

Keempat adalah administrasi. Pengadministrasian suatu program sangat penting karena hal itu merupakan bagian yang integral dalam sistem manajemen. Manajemen akan lumpuh bila administrasi tidak jalan, apalagi tidak ada. Jadi, kesuksesan manajemen tergantung pada lancar tidaknya administrasi yang dilakukan. Dari gambaran di atas, maka managemen islami bersandar pada dasar yang kokoh dari sisi perencanaa, pelaksanaan, pengawasan, akuntabiltas, dan beberapa hal lainnya yang bersandar pada nilai-nlai islami sendiri.

Hingga saat ini, ada dua jenis lembaga amil zakat, yakni yang menjadi bagian dari instrumen pemerintah serta lembaga yang didirikan oleh pihak swasta. Hingga saat ini, jumlah lembaga tersebut terus meningkat. Dengan semakin banyaknya lembaga zakat, maka, diperlukan manajemen yang profesional sesuai dengan kegiatan yang dilakukan. Setidaknya, ada empat kegiatan lembaga amil zakat, yakni penghimpunan, pengelolaan, pendayagunaan, dan pendistribusian. ${ }^{10}$

10 Hasrullah Rachim, Efektivitas Pelaksanaan Zakat di Badan Amil Zakat Kota Palopo, (Makasar: Unhas, 2012), hal. 26-37 
Manajemen yang baik tentu akan melahirkan sistem efektif dan efisien sehingga manfaat zakat mampu memberikan daya guna bagi penerima. Dengan demikian, manajemen zakat haruslah berpinsip pada nilai-nilai manajemen islami dalam menjalankan empat fungsinya tersebut.

\section{Manajemen Zakat dan Kesejahteraan Umat}

Allah telah memberikan ilmu pengetahuan zakat kepada kita semuat tentang cara pengelolaan zakat sehingga dapat mensejahterakan umat. Menurut aturan, baik yang ada pada al-Qurann dan as-Sunnah, yang bertanggung jawab atas kesejahteraan rakyatnya adalah pemerintah, karena peran pemerintah sebagai "khalifah Allah" dan sebagai "khalifah khala'ifillah". Lembaga/badan yang berhak mengelola zakat adalah pemerintah atau penguasa. Hal ini sesuai dengan pengertian dari ayat 103 surat al-tubah, hadith-hadith nabi baik yang berupa ucapan maupun yang berupa perbuatan dan kebijaksanaan para al-kbulafa rasbidin ${ }^{11}$.

Menurut al-Shaukani, zakat harus diserahkan pada pemerintah melalui aparatur negara yang disebut oleh Allah dengan "alamilin alaiba" . al-amilin dimasukkan sebagai kelompok orang-orang yang berhak menerima zakat pada urutan yang ke tiga, hal demikian menunjukkan bahwa zakat bukanlah suatu tugas kewajiban yang diserahkan pada perseorangan akan tetapi ia merupakan tugas kenegaraan. ${ }^{13}$ Pemerintah diharuskan mengurus, mengawas dan mengangkat para amil sebagai pengelola zakat baik sebagai pengumpul, penyimpan, penata buku maupun sebagai distributor, kalau tidak apa perlunya bagian amil disebutkan dalam al-Qur'an.

Sahl bin Abi Shalih mendapat fatwah dari beberapa sahabat, yaitu Sa'ad bin Abi Waqqas, Ibnu Umar, Abu Hurairah, Abu Sa'ad al-Khudri, agar harta Sahl yang sudah mencapai satu nisab zakatnya diserahkan

11 Sjechul Hadi Permono, Formula Zakat Menuju Kesejabteraan Sosial, (Surabaya: Aulia, 2005), hal.132.

12 Muhammad bin Ali al-shaukani, Nailul authar sharah muntaqal akbbar (Mesir: Musthofa al-Babi alHalabi wa Auladuh, tt), hal.190.

${ }^{13}$ Sjechul Hadi Permono, Formula Zakat, hal.133. kepada sultan (kepala negara) dan tidak ada yang menentang pendapat itu seorang pun. ${ }^{14}$ Di Indonesia, zakat telah menjadi bagian penting urusan negara dengan hadirnya Undang-Undang Nomor 38 Tahun 1999 tentang Pengelolaan Zakat sebagaimana diganti dengan UU nomor 23 tahun 2011 tentang zakat dan peraturan pendukung lainnya telah dibuat oleh pemerintah untuk memaksimalkan potensi zakat, baik dari sisi potensi pengumpulan, pengelolaan hingga pendistribusiannya.

Indonesia adalah negara muslim terpadat terbesar di dunia. $87 \%$ dari 220 juta orang di Indonesia adalah Muslim sekitar 191 juta jiwa. Menurut data penelitian dari Baznas Indonesia pada 2016 potensi zakat mencapai Rp 286 triliun. ${ }^{15}$ Sedangkan menurut keterangan dari Kementerian Agama, pontensi zakat di Indonesia sebenar Rp 217 triliun dan yang saat ini baru terealisasikan hanya $\mathrm{Rp} 6$ triliun. ${ }^{16} \mathrm{Hal}$ inilah membuat perlunya manajemen dalam pengelolaan zakat sehingga manfaatnya dapat dirasakan oleh masyarakt. Dari jumlah penduduk tersebut, 40\% (76.500.000) yang subjek untuk membayar zakat, sedangkan sisanya berhak menerima zakat. Potensi yang begitu besar, bisa menjelma menjadi instrumen kesejahteraan sosial. Artinya, zakat harus menjadi sumber untuk meningkatkan kesejahteraan sosial-ekonomi bagi masyarakat muslim di Indonesia.

Meskipun tren per tahun mengalami kenaikan, potensi yang mampu dimaksimalkan masih dinilai sedikit. Untuk mencapai hasil yang maksimal dari harta zakat, tentu nya harus dikelola secara baik oleh sebuah lembaga, baik itu lembaga yang berada dibawah naungan pemerintah, maupun

${ }^{14}$ Yusuf al-Qardhawi, Fiqh al-Zakah (Bairut: Dar al-Irsyad, tt), hal.754 dan Didin Hafiduddin, Zakat dalam perekonomian modern. Jakarta: Gema Insani, 2002, hal. 51.

15 Dikutip dari

https://www.republika.co.id/berita/dunia-

islam/wakaf/17/11/29/p05ukg335-baznas-potensi-

zakat-di-indonesia-sangat-besar. Diakses 3 Agustus 2018

16 Kementerian Agama menyebutkan, instrumen

hukum bagi zakat sudah cukup namun masih ada kendala dalam pelaksanannya. Lihat https://www.republika.co.id/berita/dunia-islam/islamnusantara/18/02/23/p4m1gs409-kemenag-potensizakat-nasional-capai-rp-217-triliun. Diakses 3 Agustus 2018 
lembaga yang bergerak di bidang swasta, serta tujuan harus memiliki tujuan yang sma yaitu untuk mensejahterakan masyarakat muslim. Probelematika zakat saat ini, sebagaimana penulis sebutkan di atas, satu diantaranya berhubungan dengan manajemen. Sebab itu, potensi yang demikian besar perlu dikelola oleh lembaga dengan managemen yang baik sesuai dengan amat aturan perundangundangan dan hukum Islam. Dalam pengelolaan zakat, ada empat hal yang menjadi bagian penting manajemen zakat oleh suatu lembaga, yakni penghimpunan, pengelolaan, pendayagunaan, dan pendistribusian.

\section{a. Penghimpunan}

Penghimpunan merupakan kegiatan yang dilakukan untuk mendapatkan dana ZIS dari muzakki. Pengumpulan dana zakat, infaq, sedekah dan wakaf yang diambil dari masyarakat merupakan peran, fungsi dan tugas bidang penghimpunan. Dalam melaksanakan aktivitas pengumpulan dana tersebut bagian penghimpunan dapat menyelenggarakan berbagai macam kegiatan. Menurut Sudewo kegiatan penghimpunan ada dua yaitu galang dana dan layanan donatur:

1. Galang dana, dalam melakukan penggalangan dana ada beberapa kegiatan yang dapat dilakukan yaitu:

a) Kampanye (dakwah)

b) Kerjasama program

c) Seminar dan diskusi

d) Pemanfaatan rekening bank

2. Layanan donator, layanan donatur tak lain adalah customer care atau di dalam perusahaan dinamakan customer service. Tugas yang dilakukan layan donatur cukup bervariasi diantaranya:

a) Data donatur, data tentang donatur harus didokumentasikan.

b) Keluhan, layan donatur juga harus sama cermatnya dalam mendata tentang keluhan dari donatur, mitra kerja atau masyarakat umum.

c) Follow up keluhan, satu hal yang menjadi kebiasaan kita adalah menghindari penyelesaian keluhan.

Dengan adanya pelayanan untuk donatur, mereka tidak merasa kecewakarena merasa tidak diperhatikan. Pencatatan nama- nama donator dirasakan sangat penting karena hal ini menyangkut hubungan silaturrahim antara muzakki, amil, dan juga mustabiq. Potensi zakat yang ada pada lembaga sangat berpengaruh pada hubungan ini. Di Indonesia, potensi zakat ini cukp besar dan banyak peneliti yang menilai bahwa zakat mampu menjadi bagian dari solusi persoalan kesejahteraan. ${ }^{17}$ Oleh sebab itu, manajemen penghimpunan ini juga

\section{b. Pengelolaan}

Tidak ada bedanya struktur keuangan zakat dengan truktur keuangan lembaga yang lain, struktur keuangan zakat terdiri atas dua bidang yaitu akuntansi dan bendahara. Ada dua verifikasi yang dikerjakan yakni verifikasi penerimaan dan pengeluaran. Verifikasi penerimaan dimulai sejak dana ditransfer dari muzakki hingga masuk ke lembaga zakat. Verifikasi dana keluar dicermatit sejak diajukan hingga pencairan dana. Mengeluarkan dana yang telah disetujui merupakan fungsi bendahara. Sedangkan pencatatan keluar masuknya uang merupakan fungsi dari bidang akuntansi. Pencatatan ini diinput dalam jurnal harian. Setelah itu diposting kedalam buku besar. Dalam kerjanya sesungguhnya akuntansi memilah atas dua segi yakni akuntansi keuangan dan akuntansi manajemen. Akuntansi keuangan dibuat sesuai pernyataan standar akuntansi, sementara akuntansi manajemen dikerjakan sesuai dengan kebutuhan lembaga.

Manajemen administrasi dan akuntansi menjadi syarat utama bagi manajemen pengelolaan di lembaga zakat. Oleh sebab itu, lambaga zakat perlu tunduk pada aturan perundang-undangan yang lain, seperti UU Informasi Keterbukaan Publik. ${ }^{18}$ Pengelolaan zakat haru memiliki perencanaan kerja dan sistem adminstasi yang lebih jelas dan tidak

17 Lihat kajian yang ditelah dilakukan oleh Canggih dkk. Clarashinta Canggih, Khusnul Fikriyah, Ach. Yasin, Potensi Dan Realisasi Dana Zakat Indonesia, Al-Uqud: Journal of Islamic Economics, 2017, 1.1: 14-26.

18 Lebih lengkap, lihat Dina Fitrisia Septiarini, Pengarub Transparansi dan Akuntabilitas Terbadap Pengumpulan Dana Zakat, Infaq dan Shodaqoh pada LAZ di Surabaya, AKRUAL: Jurnal Akuntansi, 2011, 2.2: 172199. 
bisa menjalankan lembaga hanya sesuka hati. Apalagi, zakat adalah bagian dari ibadah wajib yang harus dilakukan oleh umat Islam dan pengelolaannya juga menjadi bagian untuk mencapai tujuan syariat zakat itu sendiri. Di sinilah arti penting manajemen islami dalam pengelolaan zakat.

\section{c. Pendayagunaan}

Kreativitas divisi pendayagunaan merupakan hal yang memotori maju atau mundurnya suatu lembaga zakat, yaitu bagaimana lembaga zakat mendistribusikan dana zakat dengan inovasi-inovasi yang tentunya semakin baik dan bisa memenuhi tujuan pendistribusian dana zakat kepada mustahiq. Inti dari zakat itu sendiri adalah Pendayagunaan program pemberdayaan mustahiq. Beberapa kegiatan bidang pendayagunaan.yang dapat dikembangkan, yaitu:

a) Pengembangan ekonomi

b) Pembinaan Sumber Daya Manusia

c) Layanan sosial. ${ }^{19}$

Artinya, dana zakat bisa digunakan untuk keperluan konsumtif dan juga produktif. Namun, dalam penentuan mustahiq yang bersifat konsumtif dan produktif tersebut, perlu memiliki standarisasi yang baik. Lembaga zakat perlu memahami keinginan pembayar zakat sehingga ketidakpuasan mereka terhadap pengelolaan zakat dapat diminimalkan. Lembaga zakat juga perlu memikirkan memperbaiki dan meningkatkan perannya terutama dalam pendayagunaan dan pendistribusian zakat. ${ }^{20}$

Sebagaimana ketentuan dalam Islam, zakat mesti disalurkan kepada orang-orang atau golongan yang berhak menerima zakat atau mustahiq, yaitu delapan golongan, ${ }^{21}$ yaitu:

1. Fakir adalah orang yang tidak berharta dan tidak mempunyai mata pencaharian/penghasilan atau usaha

19 Hasrullah Rachim, Efektivitas Pelaksanaan Zakat, hal. 28

20 Muharman Lubis, dkk., Enhancement Of Zakat Distribution Management System:Case study in Malaysia, (Kuala Lumpur: disampaikan dalam Kulliyah ICT dan Didin Hafiduddin, Zakat dalam perekonomian modern. Jakarta: Gema Insani, 2002, hal. 9-37.

21 Direktorat Pemberdayaan Zakat, Manajemen Penegelolaan Zakat, (Jakarta: Depag RI, 2009), hal.36 tetap guna mencukupi kebutuhan hidupnya (bafkah), sedangkan yang menanggung dan menjaminnya tidak ada.

2. Miskin adalah orang yang tidak mencukupi kebutuhan hidupnya, meskippun ia mempunyai pekerjaan atau usaha tetap, tapi hasil usaha itu belum dapat mencukupi kebutuhan hidupnya, dan orang yang menanggung dan menjaminnya juga tidak ada.

3. Amil adalah orang/ lembaga/ badan yang bertugas mengurus zakat, baik menerima, menyalurkan atau mengelola zakat.

4. Muallaf adalah orang yang diharapkan keenderungan hati dan keyakinannya untuk beriman atau tetap beriman kepada Allah dan mencegah agar mereka tidak berbuat jahat bahkan diharapkan mereka akan membela atau menolong kaum muslimin.

5. Riqab adalah orang atau budak yang sedang berusaha membebaskan dirinya dari majikannya.

6. Gharim adalah orang yang karena kesulitan hidupnya terlilit hutang sehingga tidak mampu membayar hutangnya. Pengertian ini berkembang pada orang yang dinyatakan pailit dalam usahanya sehingga ia dalam kesulitan memenuhi kebutuhan hidupnya disamping kewajiban hutang yang harus dibayar.

7. Sabilillah adalah orang yang dalam segala usaha untuk kejayaan agama Islam. Oleh karena itu sabilillah dapat diartikan pula sebagai usaha perorangan atau badan yang bertujuan untuk kepentingan kejayaan Agama atau kepentingan umum.

8. Ibnu Sabil ialah orang yang kehabisan ongkos dalam perjalanan (bukan maksiat), baik karena tidak mencukupi, karena kehilangan maupun dirampas.

Pengertian dari masing-masing ini mengelami perkembangan makna seiring dengan dinamika sosial yang terjadi di daerah masing-masing. Konteks variable pemaknaan tersebut berbeda dalam satu negara dengan negara. Bahkan, kategori miskin saja juga 
memiliki kriteria sendiri. Oleh sebab itu, pentingnya pemahaman pengelola zakat untuk bisa menerjemahkan para penerima zakat secara kontekstual. Dan apabila telah memenuhi kriteria sebagaimana disebutkan dalam Alquran, maka zakat itu perlu segera didistribusikan agar bisa dimanfaatkan oleh mustabiq.

\section{d. Pendistribusian}

Pendistribusian adalah suatu kegiatan dimana zakat bisa sampai kepada mustahiq secara tepat. Kegiatan pendistribusian sangat berkaitan denganpendayagunaan, karena apa yang akan didistribusikan disesuaikan dengan pendayagunaan. Akan tetapi juga tidak bisa terlepas dari penghimpunan dan pengelolaan. Jika penghimpunannya tidak maksimal dan mungkin malah tidak memperoleh dana zakat sedikitpun maka tidak akan ada dana yang didistribusikan. Zakat diberikan atas golongan tertentu karena mengandung nilai-nilai ekonomi, sosial, dan spiritual. Tujuan tersebut dapat tercapai jika zakat di alokasikan kepada delapan golongan seperti disebutkan dalam alQur'an. ${ }^{22}$

Meski demikian, lembaga zakat juga perlu memperhatikan manajemen pendistribusian. Ada beberapa ketentuan dalam mendistribusikan dana zakat kepada mustahiq yaitu, mengutamakan distribusi domestik, pendistribusian yang merata, membangun kepercayaan antara pemberi dan penerima zakat. ${ }^{23}$ Pola manajemen ini patut diterapkan agar distribusi zakat sesuai dengan syariat dan mampu mencapai tujuannya, yakni kemaslahatan umat. Distribusi zakat perlu diatur secara baik agar tidak terjadi tumpang tindih dalam proses distribusi.

\section{Zakat Sebagai Program Bantu Diri Sosial}

Secara umum zakat bertujuan untuk menata hubungan dua arah yakni hubungan vertikan dan hubungan horizontal dengan sesama manusia. Artinya secara vertikal zakat

22 Said Sa'ad Marthon, Ekonomi Islam ditengah krisis Ekonomi Global, Alih Bahasa Ihmad Ikrom dan Dimyauddin, (Jakarta: Zikrul Hakim, 2007), hal. 122

23 Hasrullah Rachim, Efektivitas Pelaksanaan Zakat Di Badan Amil Zakat Kota Palopo, (Makasar: Unhas, 2012), hal. 26-37 sebagai kesyukuran, ibadah, dan wujud ketaqwaan seorang hamba kepada Allah atas segala karunia yang dianugerahkan kepadanya, sedangkan zakat secara horizontal memiliki tujuan agar mewujudkan rasa kasih sayang dan berkeadilan sosial di antara pihak yang memiliki kemampuan ekonomi yang lebih dengan pihak yang serba kekurangan dalam perekonomian serta dapat memperkecil kesenjangan sosial dan problema ekonomi umat. $^{24}$

Islam mengajarkan kita untuk saling membantu sesama umat, yang telah terstruktur dalam pilar-pilar bidang ekonomi maupun sosial, dimana setiap individu memberikan kontribusi menurut kemampuannya masingmasing untuk memenuhi visi persaudaraannya, yaitu sebagai khalifah Allah dan sebagai salah satu anggota umat. ${ }^{25}$ Salah satu cara yang dituntut oleh Islam terhadap kaum muslimin agar terlaksana kewajiban membayar zakat adalah dengan adanya lembaga zakat yang merupakan bagian yang tak terpisahkan dari rukun Islam. Deskripsi zakat merupakan bagaimana masyarakat yang kekurangan dapat memenuhi semua kebutuhan pokoknya. ${ }^{26}$

Kewajiban zakat menjadi tujuan yang bersifat agamis, moral-spiritual, finansial, ekonomis, sosial dan politik yang pada akhirnya adalah untuk mencapai kemakmuran dan kesejahteraan masyarakat. Tujuan ini dapat dirinci dalam dua aspek yakni aspek kepatuhan terhadap perintah Allah SWT dan amal shaleh kepada masyarakat. ${ }^{27}$ Keberadaan kedua aspek tersebut sama halnya kita menggambarkan pelaksanaan kehidupan secara vertikal dan secara horizontal, dalam artian melaksanakan Hablumminallah dan Hablumminannas. Segi ekonomis ialah harta benda itu harus berputar diantara masyarakat, menjadi daya dorong untuk perputaran ekonomi dalam masyarakat. Dalam konteks ini zakat bertujuan melindungi nasib fakir miskin serta untuk meningkatkan harkat dan martabat manusia ${ }^{28}$.

${ }^{24}$ Asnaini, Zakat., hal.42

25 M. Umer Chapra, Islam And The Economic Challenge, Alih bahasa Ikhwan Abidin Basri, Jakarta: Gema Insani Press, 2000), hal. 270

${ }^{26}$ Ibid

${ }^{27}$ Asnaini, Zakat., hal.43-44

${ }^{28}$ Ibid, hal. 44 
Program bantu-diri sosial yang diwakili zakat tidak seperti kewajiban sipil membayar pajak. Ia merupakan kewajiban agama yang secara mutlak mengikat dan diwajibkan oleh pencipta itu sendiri dan harus dibayarkan dari kekayaan yang Dia berikan kepada keutamaan Nya sebagai amanah yang harus dinikmati bersama-sama dan mereka yang kurang beruntung. Kurang pedulinya seseorang terhadap sesamanya akan dipandang sebagai kegagalan yang lebih serius dari pada kekurangan seseorang dalam memenuhi kewajiban Tuhan. ${ }^{29}$

Jika diperhatikan terhadap mereka yang tidak membayar pajak, serta pemerintah telah mengetahui keberadaan mereka, bisa saja sanksinya bersifat aturan Negara yakni bersifat duniawi, namun apabila tidak membayar zakat sebagai salah satu kewajiban bagi setiap muslim, bentuk pelanggarannya terjadi dalam dua kategori, yakni kategori duniawi berupa menyengsarakan sesama serta kategori ukhrowi berupa menghilangkan ketaatan kepada Allah SWT. Ada sedikit perbedaan mengenai cara orang kaya dalam memberikan sumber-sumber daya melalui zakat atau pajak ekstra sebagai pemenuhan kebutuhan orang yang membutuhkan. Mereka yang membayar zakat dengan sukarela sebagai bagian dari kewajiban keagamaan terhadap yang membutuhkan akan memperolah tambahan pahala. Sementara mereka yang membayarnya dengan paksaan atau tidak dengan keikhlasan, tidak akan mendapatkan apa-apa dari Allah. ${ }^{30}$

Disini perlu diingatkan bahwa zakat berbeda dengan pembiayaan diri yang dibuat dalam masyarakat modern untuk menyediakan perlindungan jaminan sosial bagi pengangguran, kecelakaan, usia lanjut dan kesehatan lewat pemotongan upah pekerja atau sumbangan majikan. Zakat juga tidak menggantikan kedudukan penyediaan anggaran yang dibuat oleh pemerintah untuk meringankan beban mereka yang terkena bencana dan pembayaran kesejahteraan mereka. Bahkan zakat tidak mengesampingkan tindakan-tindakan penggunaan fiskal oleh negara islam dan skema untuk melakukan redistribusi pendapatan dan ekspansi peluang pekerjaan dan wirausaha. Sebenarnya zakat adalah tindakan bantu-diri sosial yang dipakai dengan dukungan agama sepenuhnya untuk mendukung yang kurang beruntung, yang tidak mampu membantu dirinya sendiri sekalipun sudah ada skema-skema diatas, sehingga terhapus kesulitan dan kemiskinan dari masyarakat muslim. ${ }^{31}$

Berdasarkan hukum Islam tradisional, peran pemerintah merupakan instrumen dalam pelaksanaan zakat di negara muslim. Pemerintah bertanggung jawab untuk pengumpulan zakat dan mendistribusikannya. Pemerintah juga memiliki kewenangan untuk memeriksa setiap muslim untuk membayar zakat mereka. Seperti yang dilakukan Nabi Muhammad SAW yang selama hidupnya mengumpulkan dan mendistribusikan zakat. ${ }^{32}$ Dalam hal di Indonesia, pemerintah telah memberikan keleluasaan bagi lembagalembaga non pemerintahan menjadi lembaga zakat. Keterbukaan peluang ini juga mesti ditindaki secara bijak agar lembaga pengelola zakat tidak sekadar hanya menjadi lembaga yang biasa saja, melainkan juga menjadi lembaga profesional layaknya sebuah lembaga pengelola Corporate Social Responsibility (CSR) yang telah berkembang di negara-negara maju. Tetapi, karena zakat itu adalah syariat agama, bukan saja sekadar amanat hukum, maka pengelolaannya haruslah dijalankan dengan manajemen islami.

\section{Kesimpulan}

Zakat merupakan rukun Islam yang ketiga, artinya setiap muslim wajib membayar zakat dengan nisab yang telah ditentukan terkecuali kepada golongan yang 8 (delapan) asnaf. Pada dasarnya potensi zakat merupakan hal yang paling signifikan karena memberikan efek yang besar dalam mensejahterakan masyarakat. Untuk mencapai sebuah kesejateraan masyarakat khususnya bagi umat Islam sendiri, tentu dana tersebut perlu dikelola secara baik agar bisa tersalurkan tepat kepada orang-orang yang berhak menerimanya. Pada dasarnya dalam pengelolaan dana zakat yang diterima oleh masyarakat tentu dilakukan dengan

${ }^{31}$ Ibid, hal. 274

32 Saidurrahman, Op.cit., hal. 371. 
manajemen yang baik, artinya seorang manajer dalam pengelolaan zakat harus memiliki visi untuk mensejahterakan masyarakat.

Manajemen secara Islami adalah langkah awal dalam mensukseskan kegiatan mengembangkan dana zakat. Ada beberapa sistem manajemen islam yang perlu diketahui, yakni: Iman, Leadership, Manajemen dan Administrasi, keempat sistem manajemen ini sangat mendukung untuk mengembangkan dana zakat yang diterima oleh masyarakat, sehingga dengan menjalankan sistem manajemen sesuai dengan konsep Islami, hasil akhirnya adalah berupa kesuskesan dalam menjalankan lembaga.

Disamping itu pula, dalam pola manajemen zakat guna memaksimalkan sistem manjemen itu sendiri, Kegiatan yang inti (mendasar) dalam Badan Amil Zakat ada empat yaitu: penghimpunan, pengelolaan, pendayagunaan, dan pendistribusian. Dengan menjalankan pola manajemen zakat di atas, akan sangat mungkin jika masyarakat muslim menjadi sejahtera. Begitula Islam telah mengatur hubungan manusia dengan manusia dalam bentuk kepedulian terhadap sesama.] 


\section{Daftar Pustaka}

Amalia, Kasyful Mahalli. 2102. Potensi Dan Peranan Zakat Dalam Mengentaskan Kemiskinan Di kota medan. Jurnal Ekonomi dan Keuangan, Vol. 1, 70-87

Baidan, Nashruddin dan Erwati Aziz. 2014, Etika Islam dalam Berbisnis. Yogyakarta: Pustaka Pelajar.

Canggih, Clarashinta dkk, Potensi Dan Realisasi Dana Zakat Indonesia, Al-Uqud: Journal of Islamic Economics, 2017, 1.1: 14-26. [http://dx.doi.org/10.26740/jie.v1n1.p14-26]

Chapra, Umer. 2000. Islam dan Tantangan Ekonomi. Terjemahan oleh Ikhwan Abidin B. Jakarta: Gema Insani Press.

Direktorat Pemberdayaan Zakat, 2009, Manajemen Pengelolaan Zakat. Jakarta: Departemen Agama RI.

Hafidhuddin, Didin, 2002, Zakat dalam perekonomian modern. Jakarta: Gema Insani.

Hakim, Budi Rahmat Hakim Budi Rahmat, Studi Manajemen Kelembagaan Amil Zakat di Kalimantan Selatan, Tashwir, Jurnal Penelitian Agama dan Sosial Budaya 2.3 (2016). [http://dx.doi.org/10.18592/jt.v2i3.616]

Jailani, Aan, 2015, Manajemen Zakat di Indonesia dan Brunei Darussalam, Cirebon: Nurjadi Press, .

Marthon, Said Sa'ad. 2007. Ekonomi Islam; ditengah krisis Ekonomi Global. Terjemahan oleh Ahmad Ikrom dan Dimyaudin. Jakarta: Zikrul Hakim

Moleong, Lexy J. 2013. Metodologi Penelitian Kualitatif. Bandung: Remaja Rosdakarya.

Nasution, Mustafa Edwin, et al, Zakat Dan Wakaf Sebagai Pilar dalam Sistem Perekonomian Nasional, IQTISHODUNA, 2006, 1.3. [http://dx.doi.org/10.18860/iq.v1i3.205]

Razak, Mohamad Idham Md. 2013. Overview of Zakat Collection in Malaysia: Regional Analysis. American International Journal of Contemporary Research. Vol. 3, 140-148

Saidurrahman. 2013. The Politics Of Zakat Management In Indonesia The Tension Between BAZ and LAZ. Jurnal Of Indonesian Islam. Vol. 7, 366-382 [https://doi.org/10.15642/JIIS.2013.7.2.366-382]

Salleh, Muhammad Syukri. 2014. Organizational and definitional Reconfiguration of zakat management. International Journal of Education and Research. Vol. 2, 61-70

Sarea, Adel. 2012. Zakat as a Benchmark to Evaluate Economic Growth: An Alternative Approach. International Journal of Business and Social Science. Vol.3, 242-245

Sartika, Mila. 2008. Pengarub Pendayagunaan Zakat Produktif terhadap Pemberdayaan Mustahiq pada LAZ Yayasan Solo Peduli Surakarta. Jurnal La Riba. Vol. II, 35-89 [https://doi.org/10.20885/lariba.vol2.iss1.art6]

Septiarini, Dina Fitrisia, Pengaruh Transparansi dan Akuntabilitas Terbadap Pengumpulan Dana Zakat, Infaq dan Shodaqoh pada LAZ di Surabaya, AKRUAL: Jurnal Akuntansi, 2011, 2.2: 172-199. [http://dx.doi.org/10.26740/jaj.v2n2.p172-199]

Sudarwati, Yuni; Sayekti, Nidya Waras, Konsep Sentralisasi Sistem Pengelolaan Zakat Dalam Pemberdayaan Ekonomi Umat, Jurnal Ekonomi dan Kebijakan Publik, 2011, 2.1: 559-584. [https://doi.org/10.22212/jekp.v2i1.100] 